\title{
Using Hydrological Mapping to Evaluate the Effectiveness of the Bener Dam Development in Reducing Flood Risk in Purworejo Regency, Central Java
}

\author{
Sudaryatno ${ }^{1, *}$, Bagus Wiratmoko ${ }^{2}$, Winanda ${ }^{1}$, Shelly Yeni Saputri ${ }^{1}$ \\ ${ }^{1}$ Sains Information Geography, Faculty of Geography, Universitas Gadjah Mada, Yogyakarta. \\ ${ }^{2}$ Ministry of Agrarian Spatial Planning / National Land Agency \\ *) Corresponding author (email: sudaryatno@ugm.ac.id)
}

Received: 29 May 2020 / Accepted: 03 November 2020 / Published: 01 December 2020

\begin{abstract}
The Bogowonto Hulu sub-watershed has high flooding potential, especially during the rainy season. This flooding causes physical, social and economic losses for the local community and so the Bener Dam was built to reduce the volume of flooding in the area. This research aims to find out the effectiveness of the Bener Dam in overcoming the problem of flooding around the Bogowonto Hulu sub-watershed. The effectiveness of dams can be analysed by comparing the volume of the dam reservoir with the peak discharge amount generated. The value of peak discharge can be obtained using remote-sensing data and mathematical calculations following the rational method. Using this method, the estimated peak discharge value obtained for the watershed was $302.3 \mathrm{~m}^{3} / \mathrm{s}$ while the value of dam capacity was only $210 \mathrm{~m}^{3} / \mathrm{s}$, giving $92.3 \mathrm{~m}^{3} / \mathrm{s}$ of flooding potential. It is necessary to reduce the potential for flooding by building an IR reservoir in the catchment area, so that rainwater is accommodated rather than being immediately depleted, and to reduce concentration time.
\end{abstract}

Keywords: dam evaluation, peak discharge, surface runoff, Sentinel 2A imagery, Terrasar X.

\section{Introduction}

Dams are constructions built to withstand the rate of water flowing into a reservoir that are often used as hydroelectric power plants. However, the main purpose of dam construction is to reduce the impact of flooding in an area (Roehman, 2017). Nevertheless, flooding can still occur if a dam is not able to accommodate rainwater because it exceeds its capacity. Evaluation is necessary to determine the level of effectiveness of a dam.

Analysis of dam effectiveness can be carried out using spatial and mathematical approaches that compare the ability of the dam to the peak discharge in the area. Peak discharge information is crucial for infrastructure design (Camporese et al., 2010). Peak discharge calculations can be performed using data provided by remote-sensing technology and geographic information systems (GIS). Remote sensing is a technique used to find out the characteristics of a watershed area by image data analysis and interpretation related to hydrological studies, especially in the estimation of peak discharge. The rational method is a calculation method for determining the value of peak discharge indirectly that can be carried out using remote-sensing data (Grimaldi and Petroselli, 2014; Widasmara, 2019).

The rational method for determining peak discharge surface flows considers the time of concentration, and assumes that the frequency of falling rain and surface flow are the same (Arsyad, 2010). The method uses several parameters to find out the value of peak discharge, namely the coefficient of runoff, rain intensity and the area of the watershed. Parameters of the runoff coefficient are obtained from calculation results produced using the Cook method. Estimation of discharge using the rational 
method only describes the discharge peaks in a catchment area in cases of maximum intensity at a given time interval, but that value is not able to describe the capacity of the major rivers to accommodate water (Gunawan, 1991).

This study aims to determine the effectiveness of the Bener Dam in reducing the impact of flooding in Purworejo district by using remote-sensing technology and GIS to compare the dam's capacity with the peak discharge from Bogowonto Hulu subwatershed. This evaluation is expected to make it easier to formulate policies and procedures for reducing the potential for flooding in the surrounding area.

\section{Research Method}

The Bener Dam is located in Guntur village in the Bener district of Purworejo Regency at coordinates 7.596244 north latitude, 110.019062 east longitude (Figure 1). Building began in 2018 and the dam is expected to become operational in 2023. It is designed as the highest dam in Indonesia, with a height of 159 meters, a pile depth of 543 meters, and a width below 290 meters. The dam is designed to meet needs such as hydroelectric power, irrigation, raw water, tourism and flood-disaster management. In detail, the benefits of the construction of this dam comprise a watering area of 15,069 ha, reducing of flood discharge to $210 \mathrm{~m}^{3} / \mathrm{s}$, provision of a raw water supply of $1.60 \mathrm{~m}^{3} / \mathrm{s}$, and 6.00 MW of electrical power (KPPIP, 2020). One of the main factors in the decision to construct this dam was the need to reduce the flooding that often occurs in the district of Purworejo in the rainy season, especially in the area around the river Bogowonto, both in its upstream and downstream watersheds.

The research methodology is divided into three phases. The first phase determines the value of the runoff coefficient, the second phase calculates the peak discharge in the Bogowonto Hulu sub-watershed, and the third phase determines the effectiveness of the Bener Dam.

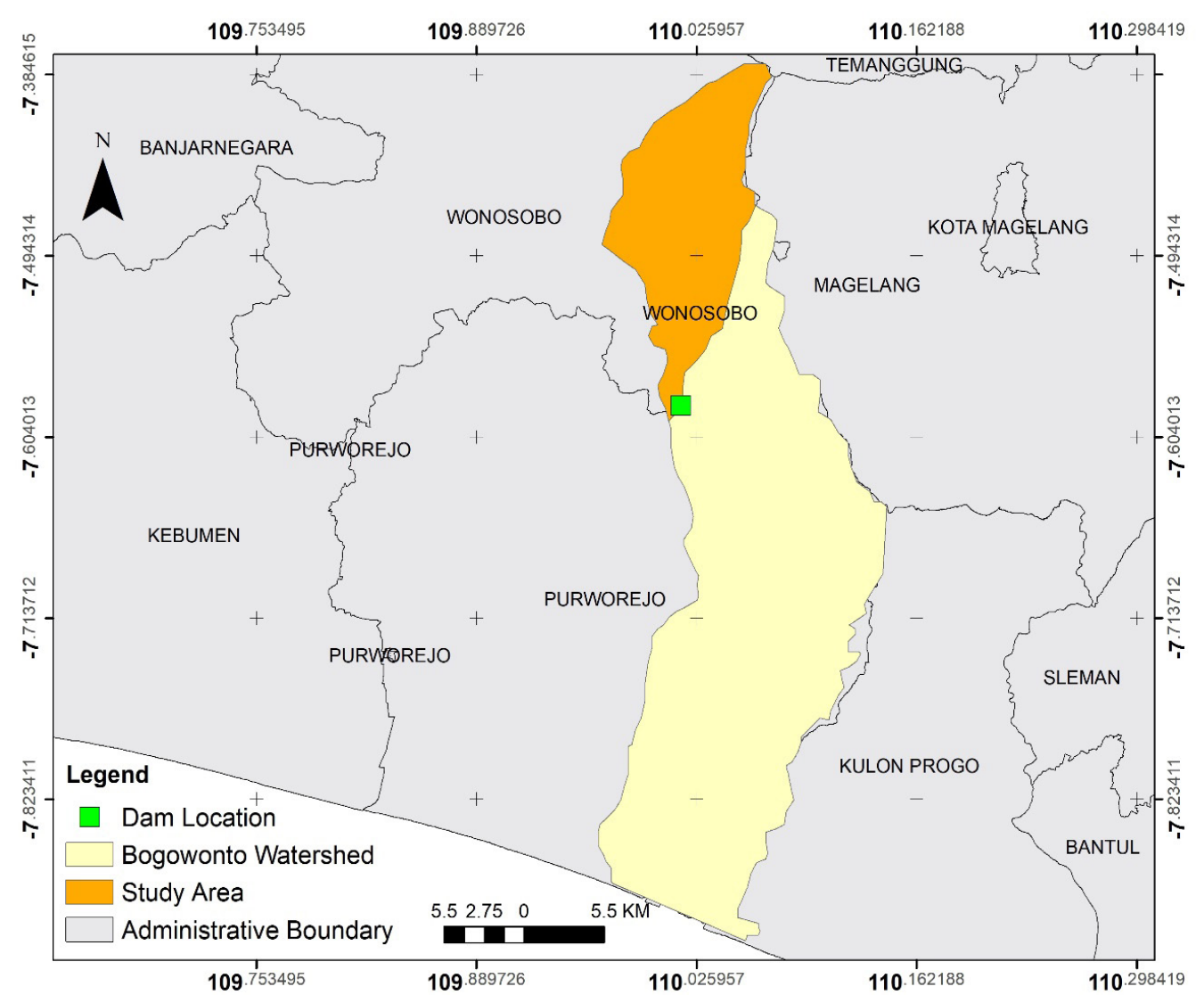

Figure 1. Study area. 


\subsection{Runoff coefficient (C)}

The runoff coefficient $(C)$ is a number that shows the ratio of surface flow to amount of rainfall. $C$ is an indicator with number range from 0 to 1 that shows the physical condition of a catchment area. The nearer the value of $\mathrm{C}$ to 1 the more rainfall that becomes flow at the surface and the less the amount of water infiltrated. In terms of watershed health, a higher value of $C$ (a value greater than $0.5)$ indicates an unhealthy catchment area. This method determines runoff coefficient values from a physical land-factor approach consisting of topography, soil infiltration, vegetation and surface runoff as in Mendonca
(2016). The technique used in calculating the $C$ value is quantitative modelling (overlay) with GIS. The result of modelling is the value of the flow coefficient in each unit of land. Runoff coefficient values are calculated using the Equation 1 (Asdak, 2010). Whereas in this equation, $C$ is runoff coefficient; $C 1,2, n$ are runoff coefficient parameters; A1, 2, $\mathrm{n}$ are area parameters. The classifications of the parameters of runoff coefficient $(\mathrm{C} 1,2, \mathrm{n})$ used in this study is based on Cook method (Table $1)$.

$$
\mathrm{C}=\frac{\mathrm{C} 1 \mathrm{A1}+\mathrm{C} 2 \mathrm{~A} 2+\mathrm{CnAn}}{\mathrm{A} 1+\mathrm{A} 2+\mathrm{An}}
$$

Table 1. Parameters of Runoff Coefficient.

\begin{tabular}{|c|c|c|c|c|}
\hline No & Parameter & Class & Characteristic & Score \\
\hline & \multirow[t]{4}{*}{ Infiltration } & Fast & Sand or other land that can absorb water quickly & 5 \\
\hline & & Medium & Deep clay with infiltration; for example, pasture soil & 10 \\
\hline & & Slow & Clay/other soils with low infiltration capacity & 15 \\
\hline & & Very slow & No effective ground cover, thin ground layer & 20 \\
\hline & \multirow[t]{4}{*}{ Drainage } & High & $>5$ & 5 \\
\hline & & Normal & $2-5$ & 10 \\
\hline & & Low & $1-2$ & 15 \\
\hline & & Ignored & $<1$ & 20 \\
\hline & \multirow[t]{4}{*}{ Slope } & $0-5 \%$ & $0-5 \%$ & 10 \\
\hline & & $5-10 \%$ & $5-10 \%$ & 20 \\
\hline & & $10-30 \%$ & $10-30 \%$ & 30 \\
\hline & & $>30 \%$ & $>30 \%$ & 40 \\
\hline & \multirow[t]{4}{*}{ Land cover } & High & Approximately $90 \%$ covered by woodland & 5 \\
\hline & & Medium & Approximately $50 \%$ covered by trees and grasses & 10 \\
\hline & & Low & Little crop cover, no crops and little natural cover & 15 \\
\hline & & No cover & No effective cover or similar & 20 \\
\hline
\end{tabular}




\subsection{Peak discharge}

Peak discharge is determined using the rational method, the basis of which is that the runoff rate will continue to grow until a specific concentration time (Tc). Tc is widely used to estimate the peak discharge of a watershed (de Almeida et al., 2014). The peak discharge $(\mathrm{Tc})$ is achieved when the entire watershed section is contributing to the flow in the outlet. The rate of input into the system is the result of rainfall with intensity I on watershed with area $\mathrm{A}$. The comparison value between the input rate and the peak discharge rate $\mathrm{Qp}\left(\mathrm{m}^{3} / \mathrm{dt}\right)$ occurring at the moment of Tc (hour) is expressed as runoff coefficient $C$, with a value of $0 \leq C \leq 1$.

The data used to calculate $\mathrm{Qp}$ is the coefficient of runoff, watershed area and rainfall intensity. The Equation 2 is the formula for rational method used to calculate the peak discharge (Qp) (Pramono et al. 2010). Whereas in the equation, 0.28 is the correction factor; $\mathrm{A}$ is the watershed area $\left(\mathrm{km}^{2}\right) ; \mathrm{C}$ is the surface runoff coefficient; and I is rain intensity ( $\mathrm{mm} /$ hour). Where the rain intensity (I) was calculated using the Equation 3. In this equation, $L$ represents the maximum length of flow $(\mathrm{m})$ and Tc represents the concentration time (hour).

$$
\mathrm{Qp}=0.28 \times \mathrm{C} \times \mathrm{I} \times \mathbf{A}
$$

$$
I=\left(\frac{R 24}{24}\right) \times\left(\frac{24}{T c}\right)^{\frac{2}{3}}
$$

\subsection{Evaluation of the effectiveness of Bener Dam}

The effectiveness of the dam can be evaluated by comparing the dam capacity with the estimated peak discharge value. If the dam capacity is greater than the peak discharge estimation, the construction of the dam will effectively remove the potential for flooding. However, if the dam capacity is less than the peak discharge estimation, the dam will not be effective in removing all flooding potential.

\section{Results and Discussion}

Effectiveness of the dam can be evaluated by comparing the amount of peak discharge that occurs with the capacity of the dam to accommodate peak discharge. The amount of peak discharge that occurs in the Bogowonto sub-watershed can be established by using the rational and Cook methods for the runoff coefficient parameters. Figures 2 presents the results from the processing of the four parameters of the runoff coefficient carried out using the Cook method, as well as the runoff coefficient results of spatial analysis using GIS.

Through overlaying the datasets, the runoff coefficients in the study area can be identified. Using the Cook method, the flow coefficient is calculated using four physical soil parameters: topography, soil infiltration, vegetation and flow density. From the results of the analysis of soil factors, the upstream C value of Bogowonto sub-watershed is quite high, at 0.658 . These results indicate that $65.8 \%$ of the rainwater is not infiltrated into the ground but becomes surface runoff. The runoff coefficient value of 0.658 is obtained from the total of overall flow coefficients in each thematic unit, because the mapping unit of the flow coefficient is a thematic mapping unit. Where each mapping unit has information for the four parameters used they are directly weighted by the area of the mapping unit. If the coefficient is calculated based on the average value of the surface flow coefficient, whose values range from 0.0001 to 2.56 (Figures 2e), compared to the number of mapping units, the results will not be representative because it will be found to generate very small flow coefficient values. 

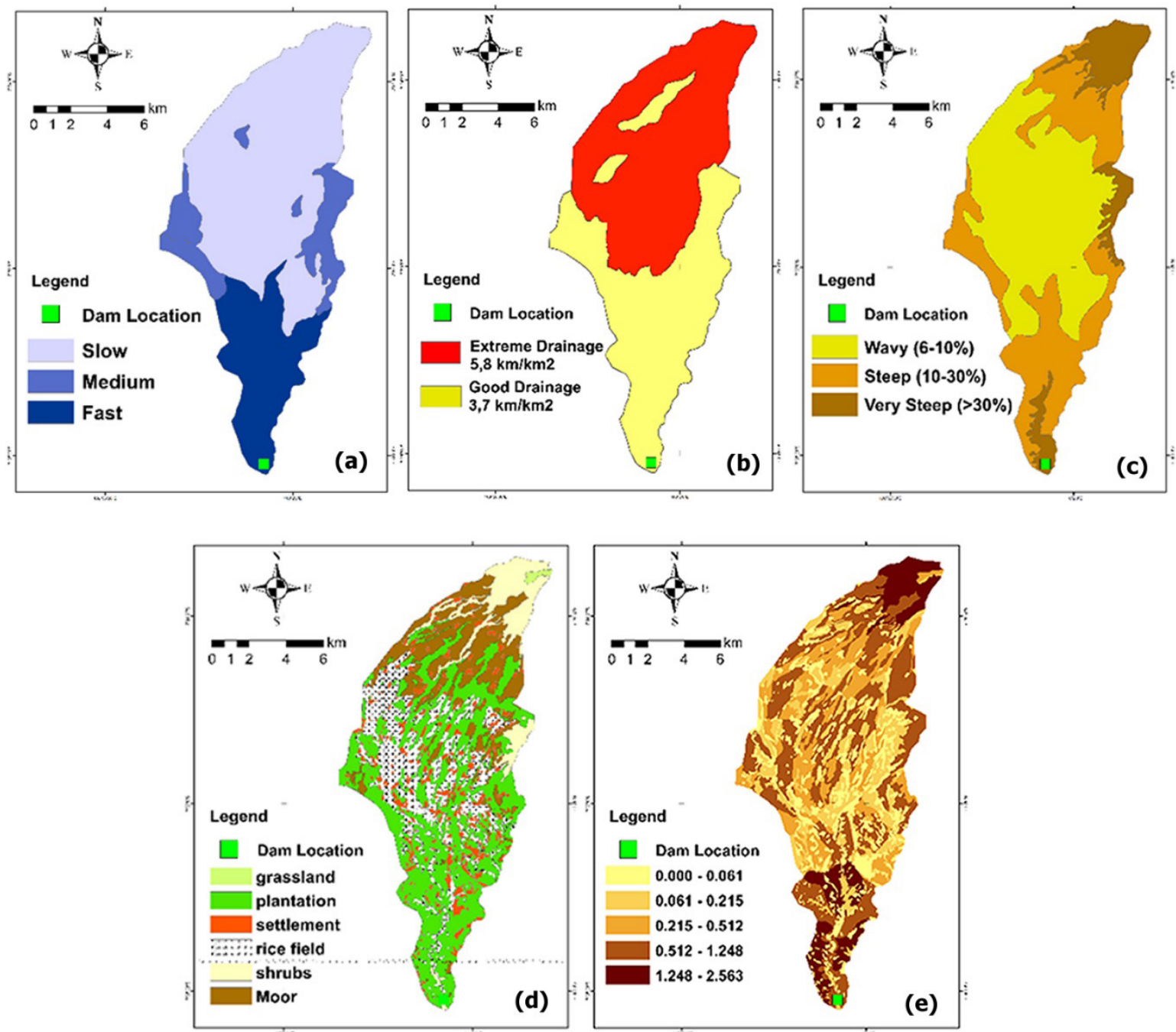

Figure 2. Datasets and the results of runoff coefficient analysis. (a) infiltration factor, (b) drainage factor, (c) slope factor, (d) land-cover factor., (e) runoff coefficient.

The size of the flow coefficient is most influenced by land cover. Based on Figures $2 \mathrm{~d}$ showing land cover, the upstream land cover is dry agricultural land (moorland). Moorland is less able to absorb or hold rainwater because moorland plants are usually short and not woody and so are less resistant to runoff. In the middle area there are paddy fields which in the rainy season are planted with rice and in the dry season with palawija, both of which are unable to withstand rainwater. Finally, in the downstream area, plantation land cover is found which is capable of absorbing rainwater because of its woody and broadleaf plants and also because plantations usually adopt the agroforestry system which alternates other planting with forest plants.
The magnitude of the flow coefficient is not only influenced by land cover, but also by slope, infiltration and flow density (Dinka, 2019). The angle of slope will affect the speed of water flow. On steep slopes, water will tend to flow at the surface because the flow velocity is higher than the level of soil infiltration. Meanwhile, on shallow slopes, the time needed for water to flow is long enough to allow soil infiltration to occur.

The processing results of runoff coefficient parameters presented in Figures 2e show that the upstream and downstream areas have slopes of $>30 \%$ while the middle section has slope of $5-10 \%$, indicating that the study area has a hilly topography, especially in the location where the Bener Dam is being constructed. 
Based on these conditions, it can be said that the potential for water to become runoff is quite high, because water flows faster on steeper slopes. In addition to slope, runoff can also be affected by soil infiltration. The greater the infiltration rate, the higher the likelihood that water will seep into the soil and vice versa. Infiltration is very closely related to soil texture. In the upstream area the soil is clay which is characterized by very strong bonding between its particles, making it difficult for water to pass through it and thus producing a slow rate of infiltration. In contrast, the downstream part of the watershed has sandy loam soil which has less strong binding capacity between particles, making for faster infiltration values than clay.

The flow coefficient is also influenced by drainage density. The closer the drainage, the faster the rainwater enters the river. Based on the results of runoff coefficient parameters as shown in Figures 2e, in the study area, drainage density is classified as good and extreme. In the upstream part, the drainage density value is $5.8 \mathrm{~km} / \mathrm{km}^{2}$ and is extreme, as influenced by resistant rocks which cause many river channels to form creating high flow density. Meanwhile, in the downstream area, the flow density is 3.7 $\mathrm{km} / \mathrm{km}^{2}$ and is classified as good. This reflects rock composition with lower resistance than upstream, so that the rivers formed are not as tightly packed as those found upstream. This drainage density is directly related to the time of rainwater concentration flowing into the river: the higher the drainage density, the more paths that carry water to the river so that runoff will be smaller because water directly flows into the river, and vice versa.

Rain intensity is measured at two raingauge stations, Guntur and Ngasinan, over a recurring period from 2000 to 2011 . The rainfall data measurements used were the highest rainfall data for each year. Calculation of rain intensity using the Thiessen and Mononobe methods produces a maximum intensity value of $1.167 .885 \mathrm{~mm} /$ hour (Table 2). According to the BMKG (Geophysical Climatology Meteorological Agency of Indonesia), this intensity is classified as heavy rainfall. The maximum intensity data is used because the expected runoff is the maximum runoff discharge, allowing it to be compared with the maximum dam capacity. The calculation results used to obtain the intensity value of rainfall around Bogowonto sub-watershed are presented in Table 2.

Table 2. Rainfall intensity using the Mononobe equation.

\begin{tabular}{cccccc}
\hline \multirow{2}{*}{ Year } & \multicolumn{2}{c}{ Rainfall $(\mathbf{m m})$} & \multicolumn{2}{c}{ Thiessen weight } & Total \\
\cline { 2 - 5 } & Guntur & Ngasinan & W_Guntur & W_Ngasinan & 5.320 .381 \\
\hline 2000 & 139 & 100 & 0.007809053 & 0.04234923 & 641.305 \\
2001 & 203 & 114 & 0.007809053 & 0.04234923 & 6.553 .014 \\
2003 & 145 & 128 & 0.007809053 & 0.04234923 & 9.082 .855 \\
2004 & 149 & 187 & 0.007809053 & 0.04234923 & 608.657 \\
2005 & 210 & 105 & 0.007809053 & 0.04234923 & 5.759 .492 \\
2006 & 141 & 110 & 0.007809053 & 0.04234923 & 4.970 .777 \\
2007 & 40 & 110 & 0.007809053 & 0.04234923 & 4.923 .923 \\
2008 & 100 & 110 & 0.007809053 & 0.04234923 & 4.761 .733 \\
\hline
\end{tabular}




\begin{tabular}{|c|c|c|c|c|c|}
\hline \multirow{2}{*}{ Year } & \multicolumn{2}{|c|}{ Rainfall (mm) } & \multicolumn{2}{|c|}{ Thiessen weight } & \multirow{2}{*}{ Total } \\
\hline & Guntur & Ngasinan & W_Guntur & W_Ngasinan & \\
\hline 2009 & 150 & 91 & 0.007809053 & 0.04234923 & 5.025 .138 \\
\hline 2010 & 150 & 137 & 0.007809053 & 0.04234923 & 6.973 .203 \\
\hline \multirow[t]{4}{*}{2011} & 140 & 159 & 0.007809053 & 0.04234923 & 7.826 .795 \\
\hline & & & Tc & & 0.140213 \\
\hline & & \multicolumn{3}{|c|}{ Intensity (max) mm/hour } & 1.167 .885 \\
\hline & & \multicolumn{3}{|c|}{ Intensity (average) $\mathrm{mm} /$ hour } & 7.896 .702 \\
\hline
\end{tabular}

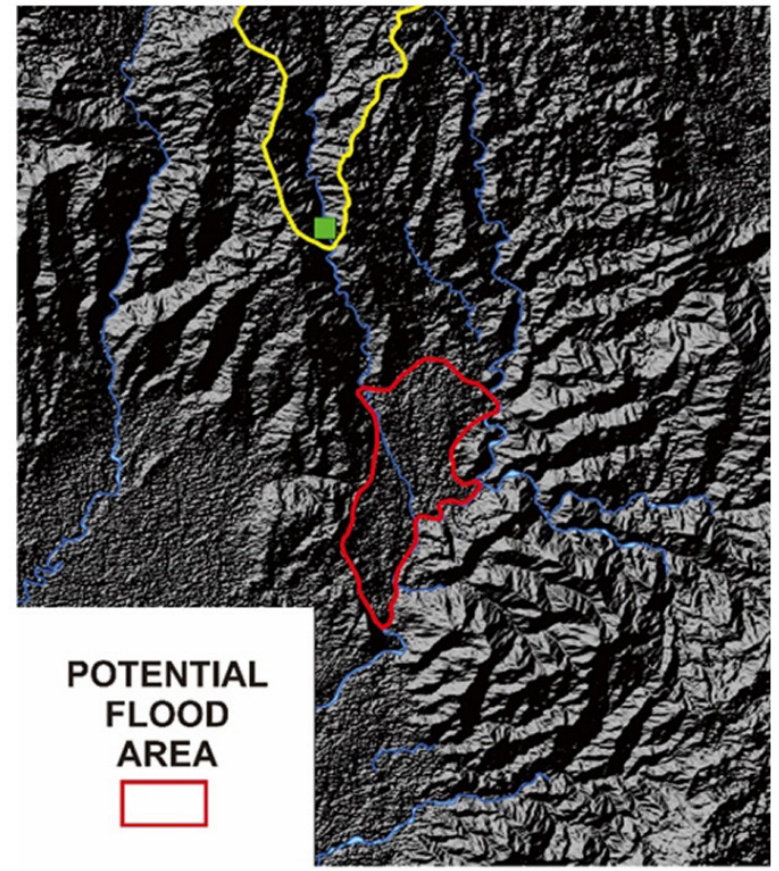

(a)

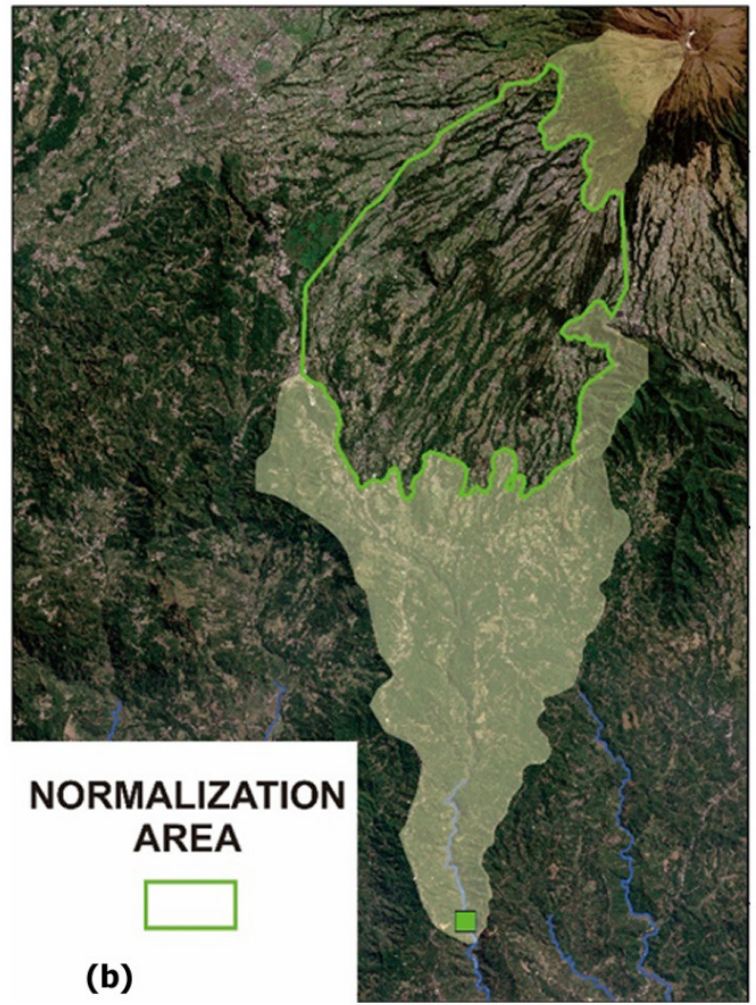

Figure 3. Area of floods potential and the mitigation. (a) flood potential area, (b) normalization area.

The runoff coefficient of the watershed is 0.658 , the maximum rainfall intensity is 11.67 $\mathrm{mm} /$ hour, and the width of the watershed is $141.6 \mathrm{~km}^{2}$. Calculating using the rational method, the peak discharge value is 302.3 $\mathrm{m}^{3} / \mathrm{s}$. According to Indonesian Public Housing and Public Works (PUPR), the maximum peak discharge capacity that can be handled by the
Bener Dam is $210 \mathrm{~m}^{3} / \mathrm{s}$ (KPPIP, 2020), and so there is the potential for excess discharge of $92.3 \mathrm{~m}^{3} / \mathrm{s}$ which could cause runoff flooding. At the downstream end of the watershed there is a fluvial area containing rice fields and community homes which would suffer adverse economic, social and ecosystem effects from such flooding. 


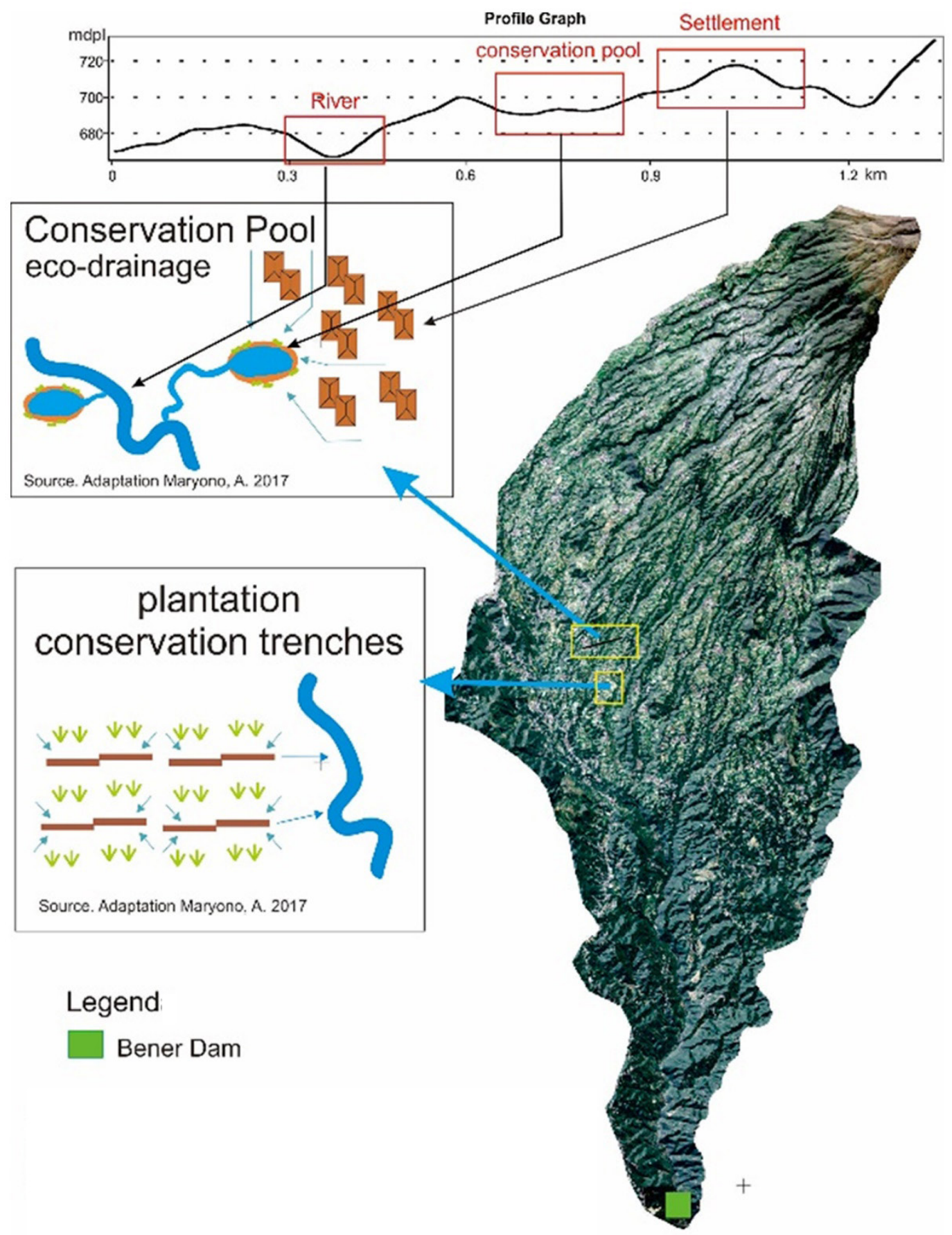

Figure 4. Eco-drainage scenario.

Based on the research results of this study, the location of the Bener Dam is not fully effective in reducing the potential for runoff flooding, because it only accommodates about $60 \%$ of total runoff discharge and thus leaves the remaining $40 \%$ as potential runoff floods (Figure 3a). Efforts can be made to reduce the potential for runoff flooding by normalizing the upstream watershed by reforestation. The focus area for reforestation in the catchment area is shown in Normalization area (Figure $3 b)$. If this upstream watershed area were properly conserved, the level of surface runoff would be reduced, but in reality, the land cover in this part of the watershed is mostly fields of woodland and vegetables that cannot absorb and withstand the level of rainfall received. Excess potential runoff could be minimized by establishing planting with lush canopies in line with appropriate conservation techniques. 
Potential flooding comes not only from the Bener Dam runoff, but also from other watersheds below that needs mitigation. It is therefore necessary to estimate peak discharge for the watersheds which also flow into the main Bogowonto river, with the peak discharge value being used as a reference to calculate the potential for runoff flooding. Besides planting, another way to reduce the potential for flooding is to build reservoirs in catchment areas (Deng et al., 2016). One or more such reservoirs would accommodate rainfall directly so as to reduce the Tc (concentration time) of runoff entering the main river (Silva, 2017). Eco-drainage (Figure 4) is an option to regulate discharge flow into the main river, by storing water on the surface to be utilized directly or absorbed into the ground, so that rainwater is not directly discharged into the river, thus decreasing the discharge load (Anggraeni et al., 2013).

This type of drainage can be applied in various locations. In residential areas, the majority of absorption can be in the form conservation ponds placed in the flow path to the river. For agricultural or plantation areas, canals can ensure that excess rainwater does not flow directly into the river (Maryono, 2018). Conservation ponds in hilly areas can be placed between settlements and streams/rivers that are located below settlements but higher than the main river, as shown in the profile graph in Figure 4.

\section{Conclusion}

Based on the estimated peak discharge value obtained of $302.3 \mathrm{~m}^{3} / \mathrm{s}$ and the ability of the dam only to accommodate discharge of 210 $\mathrm{m}^{3} / \mathrm{s}$, the dam can be projected to effectively deal with only $60 \%$ of the potential flooding around Bogowonto sub-watershed. However, further studies related to various methods of objectively establishing the level of effectiveness of dams are required, in particular because although there is one established method of calculating the percentage effectiveness of dams, there are a variety of methods available for obtaining the peak debit values of watersheds.

\section{Acknowledgements}

This research was supported by Science Information Geography, Faculty of Geography, Universitas Gadjah Mada, Yogyakarta and Ministry of Agrarian Spatial Planning/ National Land Agency. The author would like to thank the reviewers for their constructive comments.

\section{References}

Anggraeni, M., Prayitno, G., Hariyani, S., \& Wahyuningtyas, A. (2013). The Effectiveness of Biopore as an Alternative Eco drainage Technology to Control Flooding in Malang City. Jurnal of Applied Environmental and Biological Scienses, 3(2), 23-28.

Arsyad, S. (2010). Konservasi tanah dan Air. Edisi kedua. Institute Pertanian Bogor, Bogor.

Asdak, C. (2010). Hidrologi dan Pengelolaan Daerah Aliran Air Sungai: Edisi Revisi Kelima. Yogyakarta: Gadjah Mada University Press Yogyakarta.

Camporese, M., Paniconi, C., Putti, M., \& Orlandini, S. (2010). Surface-subsurface flow modeling with path-based runoff routing, boundary condition-based coupling, and assimilation of multisource observation data. Water Resources Research, 46(2).

de Almeida, I. K., Almeida, A. K., Anache, J. A. A., Steffen, J. L., \& Sobrinho, T. A. (2014). Estimation on time of concentration of overland flow in watersheds: a review. Geociências (São Paulo), 33(4), 661-671.

Deng, X., Ren, W., \& Feng, P. (2016). Design flood recalculation under land surface change. Natural Hazards, 80(2), 1153-1169.

Roehman, F. (2017). The Effectiveness Of Water-Filled Rubber Weir Management On Flood Mitigation Caused By Rain And "Rob" (Java Slang) In Demak District. In International 
Conference on Coastal and Delta Areas (Vol. 3, pp. 683-693).

Gunawan T. (1991). Application of Remote Sensing Technique to Assume Peak Discharge: Case Study in Bengawan Solo Upper Basin of Central Java. Dissertation. Bogor: University of Agriculture Bogor (IPB). p 79.

Grimaldi, S., and Petroselli, A. (2014). Do We Still Need the Rational Formula? An Alternative Empirical Procedure for Peak Discharge Estimation in Small and Ungauged Basins. Hydrological Sciences Journal 60(1): 67-77. DOI: 10.1080/02626667.2014.880546

Maryono, A. (2018). Reformasi Pengelolaan Sumberdaya Air. UGM PRESS.

Mendonca, F et al (2016). Estimating The Surface Runoff From Natural Environment Data. Management of Environmental Quality: International Journal vol. 28 No.4,2017. Emerald Publishing Limited. ISSN: 1477 - 7835.

Dinka, M. O., \& Klik, A. (2019). Effect of land use-land cover change on the regimes of surface runoff - the case of Lake Basaka catchment (Ethiopia). Environmental monitoring and assessment, 191(5), 278.

Pramono, I. B., Wahyuningrum, N., \& Wuryanta, A. (2010). Penerapan Metode Rational Untuk Estimasi Debit Puncak Pada Beberapa Luas Sub DAS. Jurnal Penelitian Hutan dan Konservasi Alam, 7(2), 161-176.

Silva, L. L. (2017). Are basin and reservoir tillage effective techniques to reduce runoff under sprinkler irrigation in Mediterranean conditions? Agricultural Water Management, 191, 5056.

KPPIP (Committee for Acceleration of Priority Infrastructure Delivery), (2020). Project Description Bener Dam. Ministry of Public Works. https:/ / kppip.go.id/ proyek-strategis-nasional/

Widasmara, M. Y., Hadi, P., \& Christanto, N. (2019). Hydrograph modeling with rational modified method. In E3S Web of Conferences (Vol. 76, p. 02007). EDP Sciences. 